AGRICULTURE AND BIOLOGY JOURNAL OF NORTH AMERICA

ISSN Print: 2151-7517, ISSN Online: 2151-7525

(C) 2011, ScienceHu $\beta$, http://www.scihub.org/ABJNA

\title{
Pasting properties of Treculia africana seed flour in Ghana and the production of a breakfast meal
}

\author{
${ }^{1}$ F. Appiah., ${ }^{2}$ I. Oduro and ${ }^{2}$ W. O. Ellis \\ ${ }^{1}$ Department of Horticulture and ${ }^{2}$ Department of Food Science and Biochemistry, Kwame \\ Nkrumah University of Science and Technology, Kumasi, Ghana.
}

\begin{abstract}
Treculia africana (African breadfruit) of the family Moraceae is an underutilized and neglected fruit plant. The seeds of the plant are edible. However, T.africana is not commonly used as food in Ghana. In order to promote its use as food, this study was conducted to determine the pasting properties of the flour derived from the seeds. Treculia africana seed flour had maximum viscosity of $40.00 \mathrm{BU}$, final viscosity $(40.00 \mathrm{BU})$, setback $(2.00 \mathrm{BU})$, breakdown $(2.00 \mathrm{BU})$ and pasting temperature of $69.4^{\circ} \mathrm{C}$. Breakfast meal produced with Treculia africana and soyabean composite in the ratio of 9:1was of acceptable quality (1.8). Seed flour of Treculia africana has good physico-chemical properties and could be used to play functional roles in food systems.
\end{abstract}

Keywords: Treculia africana, physicochemical properties

\section{INTRODUCTION}

Treculia africana (African breadfruit) belong to the family Moraceae (Ragone, 2006; Orwa et al.2009). It enjoys wide distribution in West Africa. It grows best in equatorial lowlands below 600-1550m above sea level. T.africana is distributed within lattitudes $17^{\circ}$ $\mathrm{N}$ and S. Treculia africana is used as food in some African countires such as Nigeria (Orwa et al., 2009). Treculia africana is found usually in forests in Ghana. However, it is a neglected and an under-utilized plant which has potential as food security crop. Although it is edible no scientific work has been done in Ghana on the plant. There is therefore insufficient scientific information on the crop in Ghana. The focus of this study was to determine the pasting properties of T.africana seed flour and assess it potential for breakfast meal production.

\section{MATERIALS AND METHODS}

Fresh mature fruits of Treculia africana were collected at Twifo Praso in the Central Region of Ghana. Seeds were extracted from the fruits and dried in an oven at $60^{\circ} \mathrm{C}$ for 24 hours, dehusked, milled in a hammer mill and then sieved to obtain the flour. The flour was kept in a low density polyethylene plastic bag and kept in a refrigerator prior to use.

Pasting characteristics : The pasting viscosity of the breadfruit flour samples was determined in triplicates using a Brabender amylograph (800141 OHG, Diusburg, Germany) fitted with a pin stirrer. Forty five (45) millilitres of water to give 450-g slurry (requirement of the amylograph). The slurry was heated from $30-92^{\circ} \mathrm{C}$ at a uniform rate of $1.5 \mathrm{C} / \mathrm{min}$ under a constant stirring speed of $75 \mathrm{rpm}$. The torque was continuously monitored. It was followed by cooling at a controlled rate of $1.5 \mathrm{C} / \mathrm{min}$ to $52^{\circ} \mathrm{C}$. Peak viscosity, setback value and gelatinization index were reported in Brabender units (Damardjati and Luh, 1987).

Breakfast meal development: Composite flours of $T$. africana and soybeans were formulated. Levels of substitutiton of soyabean for T.africana were $0 \%$, $10 \%, 30 \%, 50 \%, 70 \%$, and $90 \%$. The flour blends were used to prepare breakfast meals (porridge) and sensory evaluation carried out. The most consumerpreferred composite was prepared into an instant meal. A thousand gram $(1000 \mathrm{~g})$ flour was kneaded with $300 \mathrm{ml}$ distilled water. The dough was divided into 2 equal halves and baked in an oven at $120^{\circ} \mathrm{C}$ for 1 hour cooled and milled in a hammer mill to obtain the instant breakfast meal.

Chemical composition: Proximate determinations were carried out using standard procedures. The moisture content, ash and crude fibre contents were determined using AOAC (1990) recommended procedures. The Khjedahl method was used to determine the nitrogen content. Crude protein content was calculated by multiplying the nitrogen content by the factor 6.25. Crude fat was extracted for 16 hours using petroleum ether according to the Soxhlet procedure. Carbohydrate content was determined by difference.

Sensory evaluation: Twenty-member trained sensory panelists were selected from Kwame Nkrumah University of Science and Technology, 
Kumasi, Ghana. A 5-point hedonic scale was used in scoring the products; 1-Like very much; 2- Like slightly; 3- Neither like nor dislike; 4- Dislike slightly and 5- Dislike very much (Ihekoronye and Ngoddy, 1985; Chinma and Gernah, 2007).

Statistical analysis: All data were collected in triplicate. Analysis of variance was conducted using Statistix9 statistical software. Least significant difference (LSD) was used to determine differences between means. Standard deviations were also computed on data collected.

\section{RESULTS AND DISCUSSION}

\section{Pasting properties of Treculia africana seed flour:}

The pasting properties of T.africana seed flour has been presented in Table 1 . The pasting temperature of T.africana in this study was higher $\left(69.4^{\circ} \mathrm{C}\right)$ than cassava starch $\left(64.2^{\circ} \mathrm{C}\right.$; Dzogbefia et al., 2008). This indicates that T.africana seed flour cooks at a higher temperature and therefore likely to scorch during cooking (Zobel, 1988) since it. This means frequent stirring would be necessary during cooking.

The maximum viscosity of T.africana seed flour (40BU) is lower than cassava starch (660BU; Dzogbefia et al., 2008) and maize 90 BU (SefahDedeh et al., 2004). This implies that T.africana seed flour forms less viscous paste during cooking than cassava and maize. The setback (8.00BU) and breakdown (2.00BU) viscosities of T.africana flour pastes were low. Jimoh and Olatidoye (2009) reported that low setback and breakdown viscosities of a flour pastes suggests the flour starch would have a high stability against retrogradation. The low setback and breakdown viscosities observed in this study therefore suggest that pastes of T.africana seed flours has high resistance to retrogradation and therefore would form stable paste. Paste stability is an important property in porridges.

The final viscosity (40.00BU) was the same as the maximum viscosity $(40.00 \mathrm{BU})$. The final viscosity indicates the consistency at which the cooked paste of T.africana seed flour is likely to be consumed (Zobel, 1988).It also shows how far that maximum viscosity obtained during cooking of a flour paste is restored upon cooling to $50^{\circ} \mathrm{C}$. Since the maximum viscosity and the final viscosities of T.africana flour were the same it shows that the cooked paste of T.africana flour is stable.

Table 1: Pasting properties of Treculia africana seed flour

\begin{tabular}{|l|l|}
\hline Pasting property & Value $(\mathrm{BU})$ \\
\hline Beginning of gelation & $9.00 \pm 0.00$ \\
\hline Maximum viscosity & $40.00 \pm 0.00$ \\
\hline Start of holding & $32.00 \pm 0.00$ \\
\hline Start of cooling & $38.00 \pm 0.00$ \\
\hline Stability of hot paste & $6.00 \pm 0.00$ \\
\hline End of cooling & $46.00 \pm 0.00$ \\
\hline Final viscosity & $40.00 \pm 0.00$ \\
\hline Stability of cold paste & $6.00 \pm 0.00$ \\
\hline Setback & $8.00 \pm 0.00$ \\
\hline Breakdown & $2.00 \pm 0.00$ \\
\hline Pasting temperature $\left({ }^{\circ} \mathrm{C}\right)$ & $69.40 \pm 0.00$ \\
\hline TTPV (seconds) & $2080 \pm 0.00$ \\
\hline
\end{tabular}

TTPV - Time taken to reach peak viscosity

Product development: Composite flours of T.africana and soyabeans were formulated. The formulated flours were prepared into breakfast meal (porridge). Proximate composition of the various composite flours was determined and sensory evaluation conducted on porridge prepared from the flour blends.

Table 2 shows the proximate composition of Treculia africana seed flour. The moisture content of the flours varied from $6.12 \%$ (soyabeans) to $10.81 \%$ (T.africana). The moisture contents were below reported range (12-15\%) for flours (California Wheat Commission, 1999). According to Oduro et al. (2009) higher moisture of foods encourages growth of microorganisms and spoilage. The California Wheat Commission (1999) reported that at higher moisture contents rapid hydrolysis of lipids by proliferating molds seriously lowers flour quality. The lower moisture contents of the flours are suggestive that the flours would have longer shelf life. 
Agric. Biol. J. N. Am., 2011, 2(2): 325-329

Table 2: Proximate composition of T.africana:Soyabeans flour blends

\begin{tabular}{|l|l|l|l|l|l|l|}
\hline TA:SB & Moisture & Crude protein & Crude fat & Crude fibre & Ash & Carbohydrates \\
\hline $100: 0$ & $10.81 \pm 0.43$ & $17.57 \pm 0.35$ & $9.08 \pm 0.14$ & $2.91 \pm 0.08$ & $2.64 \pm 0.04$ & $57.00 \pm 0.33$ \\
\hline $90: 10$ & $7.85 \pm 0.31$ & $20.36 \pm 0.06$ & $12.47 \pm 0.14$ & $3.44 \pm 0.06$ & $3.28 \pm 0.02$ & $52.6 \pm 0.23$ \\
\hline $70: 30$ & $6.84 \pm 0.10$ & $24.19 \pm 0.09$ & $14.54 \pm 0.23$ & $3.97 \pm 0.23$ & $3.46 \pm 0.03$ & $47.0 \pm 0.31$ \\
\hline $50: 50$ & $7.1 \pm 0.11$ & $31.08 \pm 0.13$ & $16.37 \pm 0.22$ & $4.6 \pm 0.28$ & $4.06 \pm 0.06$ & $36.79 \pm 0.41$ \\
\hline $30: 70$ & $5.6 \pm 0.23$ & $35.24 \pm 0.04$ & $18.81 \pm 0.02$ & $5.12 \pm 0.34$ & $5.07 \pm 0.04$ & $30.16 \pm 0.33$ \\
\hline $10: 90$ & $4.62 \pm 0.13$ & $44.11 \pm 0.15$ & $20.9 \pm 0.07$ & $5.76 \pm 0.25$ & $5.39 \pm 0.03$ & $19.22 \pm 0.38$ \\
\hline $0: 100$ & $6.12 \pm 0.01$ & $45.86 \pm 0.22$ & $23.06 \pm 0.11$ & $6.34 \pm 0.18$ & $5.57 \pm 0.07$ & $13.05 \pm 0.37$ \\
\hline
\end{tabular}

TA - T.africana flour; SB soyabean flour

The protein content of the blends increased with increased soyabean levels and ranged between $17.57 \%$ and $45.86 \%$ (Table 1). Fasasi et al. (2004) reported a protein content of $15.1 \%$ while Giami et al. (2000) reported $20.1 \%$ for T.africana seed flours. The variation may be due to varietal differences. The protein content of T.africana in this study (17.57\%) is lower than what has been reported for soyabean $(50.8 \%)$ but higher than that of maize (7.6\%), (Nyotu et al.,, 1986). The high protein content of T.africana seed flour shows that it could be useful in ameleorating protein deficiency conditions such as Kwashiorkor (PAG,1971). The inclusion of T.africana in diets such as maize-based preparations could enhance protein intake as well as diversify its use.

The crude fat content of T.africana seed flour (9.08\%) was lower than in oil seeds such as soya bean (17.7 $\%$; Ihekoronye and Ngoddy, 1985) but higher than Bambara groundnut (6\%; Ihekoronye and Ngoddy, 1985). The moderate oil yield of T.africana seeds indicates it might not be a very good source of oil but could be useful as a source of energy. Treculia africana oil is edible and may have industrial potential. Oil improves palatability as well as being a solvent for oil soluble vitamins. Oils are essential in diets as they increase the palatability of foods by absorbing and retaining their flavours, in addition to being vital in the structural and biological functioning of cells and in the transport of nutritionally essential fat-soluble vitamins.

The composite flours had crude fibre content between 2.6 and $5.6 \%$. The crude fibre content of raw T.africana seed flour was $2.91 \%$. The fibre content is higher than peeled yam (1.45\%; Ihekoronye and Ngoddy, 1985) but lower than Tiger nut (6.26\%; Oladele and Aina, 2007). According to
Codex Alimentarius Commission (2000) the crude fibre content for weaning foods should not be greater than 5\%. Consequently, the low crude fibre content of the flour in this study makes it potential source of crude fibre in infant formulations. Intake of fibre has been recommended for combating constipation and preventing of colon cancer. The inclusion of T.aficana flours could help increase dietary bulk of foods.

The ash content of T.africana seed flour was 2.64\%; lower than 3.1\% reported by Nelson-Quartey (2007) for Artocarpus camansi but higher than sweet potatoes (0.66-1.98\%; Ihekoronye and Ngoddy, 1985). The high ash content of the flour suggests T.africana could be good source of dietary minerals. The higher ash content of T.africana seed flour is suggestive that it could be a better source of minerals than maize (0.5\%; Ihekoronye and Ngoddy, 1985).

Treculia africana seed flour had the highest carbohydrate content (57.01\%) among the flour blends. The carbohydrate content of T.africana is lower than maize (66.0\% to $75.9 \%$; Ortega, 1986$)$ but higher than winged bean (36.5\%; Ihekoronye and Ngoddy, 1985). Carbohydrates are inexpensive source of food energy. The high carbohydrate content of the flour therefore makes T.africana flour a good source of energy (Brown, 1991).

Sensory evaluation of porridges from T.africanasoyabean flour blends: Table 3 shows the mean scoring for sensory parameters by the sensory panelists. The colour of the porridge prepared from flour blend (T.africana-Soyabeans) 100:0 (1.7) was most preferred followed by $\% 0: 50$ and 70:30. The preference for 100:0 probably could be due to its lighter colour. Increasing levels of soyabeans resulted in darker colouration. 
Agric. Biol. J. N. Am., 2011, 2(2): 325-329

Table 3: Sensory scoring by panelists for breakfast meals produced with T.africana-soya composite flours

\begin{tabular}{|l|l|l|l|l|l|l|}
\hline Sensory parameter & $100: 0$ & $90: 10$ & $70: 30$ & $50: 50$ & $30: 70$ & $10: 90$ \\
\hline Colour & 1.7 & 2.9 & 2.8 & 2.6 & 3.0 & 3.1 \\
\hline Mouthfeel & 2.2 & 2.3 & 3.4 & 3.4 & 3.8 & 3.8 \\
\hline Aroma & 2.5 & 1.2 & 1.3 & 1.3 & 1.4 & 1.3 \\
\hline Taste & 2.4 & 1.3 & 2.4 & 3.1 & 3.1 & 3.2 \\
\hline Overall acceptability & 3.2 & 1.8 & 2.5 & 2.6 & 3.2 & 3.7 \\
\hline
\end{tabular}

Key: 1 - like very much; 2- like slightly; 3- neither like nor dislike; 4- dislike slightly; 5- dislike very much

Porridges produced from composited $100: 0$ and $90: 10$ had the most acceptable mouth feel (2.2-2.3). The preference of the sensory panellists for the mouth-feel of porridges produced using the 100:0 and 90:10 composite flours could be due to the thicker pastes (bodied) formed during cooking attributable probably to their higher carbohydrate contents (57.0\% and $52.6 \%$ for $100: 0$ and $90: 10$ respectively). The flours with higher levels of soyabeans produced the most acceptable aroma (1.2-1.4) as against 100:0 (2.5). The taste of porridge produced from 90:10 (1.8) was the most acceptable.

The results show that porridge prepared using only T.africana seed flour scored averagely. Substituting $10 \%$ of T.africana with soyabean flour resulted in the highest overall acceptability (1.8). This could be attributable to improved aroma (1.2), taste (1.3) and mouthfeel (2.3) imparted by the porridge. Further increasing the soya bean content of the composite meal resulted in progressive decline in acceptability.

\section{CONCLUSION}

The high protein content $(17.57 \%)$ of T.africana would enable consumers to use it for supplementing protein intake. The low maximum viscosity (40.00BU) as well as low setback (7.67BU) and low breakdown (2BU) make it suitable for breakfast meal or as weaning food. The good pasting properties of T.africana flour makes it useful food ingredient and could therefore be used in food systems where paste stability is required.

\section{REFERENCES}

AOAC (1990). Official Methods of Analysis. Association of Official analytical Chemists $15^{\text {th }}$ Edition, Washington D. C., pp 235-237.

California Wheat Commission (1999). Description of wheat quality factors. Flour analysis. http://www.californiawheat.org/Eng\%20Non\%20Durum $\% 20 C Q / 1999 / q u a l i t y \_$factors.htm
Chinma, C. E., Alemede, I. C., and Emelife, I. G. (2008). Physicochemical and functional properties of some Nigerian cowpea varieties. Pakistan Journal of Nutrition 7(1): 186-190.

Codex Alimentarius Commission Amendment Regulations (2000). The Processed Cereal-Based Foods and Baby Foods for Infants and Young Children.

Damardjati, D.S. and Luh, B.S. 1987. Physicochemical properties of extrusion - cooked rice breakfast cereals. Proceedings of the $7^{\text {th }}$ World Congress of Food Science and Technology. Trends in Food Processing 1: Membrane Filtertion Technology and Thermal Processing and Quality of Foods, October (A.H. Ghee, L.C. Kuan, C. Tan, S. Chang, J.C. Chaftel and P.J. Frazier., eds.) pp. 251-264, Singapore.

Dzogbefia, V. P., Ofosu, G. A. and Oldham, J. H. (2008). Physicochemical and pasting properties of cassava starch extracted with the aid of pectin enzymes produced from Saccharomyces cerevisiae ATCC52712. Scientific Research and Essay 3 (9): 406-409.

Fasasi, O. S., Eleyinmi, A. R., Fasasi, A. R., and Karim,O. R. (2004). Chemical properties of raw and processed breadfruit (Treculia africana) seed flour. Food, Agriculture and Environment 2 (1): 65-68.

Giami , S. Y., Adindu, M. N., Akusu, M. O. and Emelike, J. N. (2000). Compositional, functional and storage properties of flours from raw and heat processed African breadfruit (Treculia africana Decne) seeds. Plant foods for human nutrition (Dordrecht, Netherlands) 55(4):357-368.

Ihekoronye, A. I. and Ngoddy, P. O. (1985). Integrated Food Science nad Technology for the Tropics. MacMillan Publishers, London.

Jimoh, K. O. and Olatidoye, O. P. (2009). Evaluation of physicochemical and rheological characteristics of soyabean fortified yam flour. Journal of Applied Biosciences 13:703-706

Nelson-Quartey, F. C., Amagloh, F. K., Oduro, I., Ellis, W. O. (2007). Formulation of an infant food based on 
Agric. Biol. J. N. Am., 2011, 2(2): 325-329

breadfruit (Artocarpus altilis) and breadnut (Artocarpus camansi). Acta Hort. (ISHS) 757:212-224

Nyotu, H. G., Alli, I., and Paquette, G. (1986). Soy supplementation of a Maize based Kenyan Food (Ugali). Journal of food Science 51 (5):1204-1207.

Oduro, I., Larbie, T. N. E. Amoako, and Antwi-Boasiako, A. F. (2009). Proximate composition and basic phytochemical assessment of two common varieties of Terminalia catapa (Indian Almond). Journal of Science and Technology 29 (2): 1-6.

Oladele, A. K and Aina, J. O. (2007). Chemical composition and functional properties of flour from two varieties of tigernut (Cyperus esculentus). African Journal of Biotechnology. 6(21): 2473-2476

Ortega, E. I., Villegas, E. and Vassal, S. K. (1986). A comparative study of protein changes in normal and quality protein maize during tortilla making. Cereal Chem. 63: 446-451.

Orwa C, A Mutua, Kindt R, Jamnadass R, S Anthony. 2009 Agroforestree Database:a tree reference and selection guide $\quad 4.0$ (http://www.worldagroforestry.org/sites/treedbs/treedat abases.asp)

PAG (1971). Protein Advisory Group guideline no. 8. Protein-rich mixtures for use as weaning foods. New York. FAO/WHO/UNICEF.

Ragone, D. (2006). Artocarpus altilis (breadnut). Moraceae (mulberry family) Species Profiles for Pacific Island Agroforestry pp 1-17

Ragone, D. (2006). Artocarpus camansi (breadnut). Moraceae (mulberry family) Species Profiles for Pacific Island Agroforestry pp 1-11

Sefah-Dedeh, S., Cornelius, B., Sakyi-Dawson, E and Ohene Afoakwa, E. (2004). Effect of nixtamalization on the chemical and functional properties of maize. Food Chemistry86: 317-324.

Zobel, H. F. 1988. Molecules to granules: a comprehensive starch review. Starch 40:44-50. 